ARTICLE

\title{
Indigenous Public Administration: A Review and Deconstruction of the Idea, Concept, and Theory of Government and Governance
}

\author{
Suripto, " Torontuan Yeremias Keban, and Sri Harjanto Adi Pamungkas \\ Universitas Gadjah Mada, Bulaksumur, Caturtunggal, Sleman, Daerah Istimewa Yogyakarta
}

How to cite: How to cite: Suripto., Keban, Torontuan Y., and Pamungkas, Sri H A., 2021. Indigenous Public Administration: A Review and Deconstruction of the Idea, Concept, and Theory of Government and Governance. Jurnal Borneo Administrator, 17 (3), 305-318. https://doi.org/10.24258/jba.v17i2.932

\author{
Article History \\ Received: 18 July 2021 \\ Accepted: 16 December \\ 2021 \\ Keywords: \\ Indigenous, \\ Governance, \\ Public Administration, \\ Incompatibility
}

\begin{abstract}
Indigenous Public Administration (IPA) has attracted researchers' attention and awareness of the importance of developing contextual theory and practice of public administration, especially in developing countries such as Indonesia. IPA emerges in many developing countries since the concept, theory and practice of Western Public Administration (WPA) have failed to respond to local issues, and therefore WPA practice is considered irrelevant. Basically, IPA is a constructed concept to fill a vacant space that unoccupied by Western Public Administration (WPA). This descriptive qualitative study aims to explain and criticize the theory and practice of IPA and WPA. The data were gathered from books, journals, institution reports, regulations and other relevant writings of organizations, professionals, and academicians. The technique of data analysis was based on a data analysis spiral. It reveals that IPA applies to countries such as Indonesia and China. In both countries, the practice of IPA helps to overcome public issues concerning social, economic, and political. It is expected that the findings of this study will pave the way for developing both concept and theory of IPA and responding to more complex society and government's demands and needs.
\end{abstract}

\section{A. INTRODUCTION}

Indigenous Public Administration (IPA) has become the most discussed topic after some criticisms about Western Public Administration (WPA) rose. Many researchers emphasize that the success or failure of public administration theory and concept depends on a crucial aspect of contextuality. WPA is a non-contextualized concept to be applied in some developing countries. Therefore, IPA becomes a viable alternative getting more popular among topics in public administration studies (Wang \& Liu, 2018:122). This situation is mainly caused by WPA's concept, theory, and practice to respond to local culture (indigenous) in some developing countries. So the practice of WPA is considered less relevant (Cheung, 2013:251; Drechsler, 2013:321; Dwivedi, 2002:48; The College of Public Administration University of the Philippines, 1981:18-20).

Aceh and Papua are two provinces that have failed to apply WPA. With its secular characteristic, WPA is not applicable to respond to the reality of social, economic, and political issues in Aceh where Islamic principles are embedded in community living in this province. This

\footnotetext{
* Corresponding Author

Email:ripto@ugm.ac.id
} 
led to the emergence of the separatist movement for decades that demanded a fairer fiscal balance and sharia principle enforcement. The Government of Indonesia granted these requests by signing the peace treaty with the Free Aceh Movement. Clauses 10 and 12 in Law Number 11 of 2006 provide a clear mandate to reform local public administration in Aceh. There are various dynamics concerning the forming of public administration in Aceh in the context of public administration reform which put more concern on local characteristics (Hillman, 2013:149-169).

In addition, WPA implemented in Papua based on meritocracy clashes with social, economic, and political issues. The ethnicity-based relationship strongly influences it. Papuan people have primarily lived with their local wisdom. They live under two leadership systems: kingdom leadership system and mixed leadership system (Deda et al., 2014:16). Papuans philosophically believe in religion and magic (religious-magical relationship). This matter also becomes the other factor contributing to the emergence of the separatist movement up to the present day. Similarly, this condition also occurred in the Republic of the Congo, Africa, where centralization-based WPA failed to manage heterogeneous communities (Acemoglu \& Robinson, 2012:62). Provinces such as Katanga and Kasai then shifted onto the separatist movement bases.

This study is fundamentally conducted to pave the way for establishing and developing the concept and theory of IPA. Even though IPA is an alternative discourse and increases enthusiasm for discussion, there is still a relatively slight review and implementation. In other words, in modern countries, IPA is somewhat disregarded. However, in some countries such as China, South Korea, and the Philippines, IPA has contributed as an essential pillar of public administration. A variety of situations concerning the implementation of IPA have been marginalized by WPA hegemony.

Meanwhile, the role of IPA is significant in some cases. Through this study, more comprehensible issues of IPA can be explored. There are three main discussions. First, the idea of WPA is discussed to understand it fully. It is an essential benchmark for understanding WPA as the mainstream of modern public administration. Second, the concept of IPA is also discussed to comprehend it deeply. It is expected to become the foundation to observe the role of IPA as an alternative discourse. Third, the discussion focuses on implementing IPA in China and Indonesia. China was selected for several reasons: the availability of references, the abundance of local wisdom and one of the oldest, the successful implementation of IPA in the national scope, and the significant impact of IPA on public administration in China. Meanwhile, Indonesia was chosen to learn the presence of IPA, influence, and make advance development. This study also shows great significance for an IPA discourse in Indonesia.

According to the classical thinkers of public administration such as Max Weber, Woodrow Wilson, Goodnow, and Hamilton, public administration refers to the activities of the executives and their inferior institutional branches. Therefore, these classical views clearly explained that the scope of public administration is associated with the executive institutions, including their activity domains.

However, the development of dynamic perspectives brought the ideas beyond the classical views, such as the ideas of citizenship (Bourgon, 2007:15-21) and public value (Bozeman, 2007: 145; Bryson et al., 2014:448). Bourgon, one of the modern thinkers, tries to expand the scope of public administration, the executives, and the interaction between citizens and the state. Furthermore, Bozeman, Bryson, Crosby, and Bloomberg view the relationship among stakeholders in creating public value. The public administration and its scope are widely defined when associated with public value. Non-Governmental Organizations (NGO) and private companies, not affiliated with the executives, are included in public administration when related to public value. For example, World Intellectual Property Organization (WIPO) conducts governance and service for global intellectual property rights protection. 
The contemporary definition and scope of public administration will be used for conceptual analysis. They will open a more expansive space for discussing public administration phenomena. One of them is to learn how society establish, own, and carry out the practice of public administration which distinguishes it from WPA. These practices emerge from and are based on local wisdom reflected in people's daily life. Something is known as a concept of "indigenization".

So far, the concept and practice of public administration in some developing countries, including Indonesia, refer to those used by developed countries (western countries) (Drechsler, 2013:321). To refer to the existing concept and practice is allowed. The problem is if an imitative practice dominates and marginalizes the local context and existing IPA implemented in a long period (The College of Public Administration University of the Philippines, 1981:7). Imitation becomes problematic when a country later faces a crisis that proves that the concept and practice are not relevant to the condition and problem in that country (The College of Public Administration University of the Philippines, 1981:18). Commonly, many imitative practices have been found in some developing countries. Institutional development is performed based on the theory and practice of WPA. However, the results are not as good as in western countries.

Implementing WPA in other countries can provide a valuable lesson for Indonesia. Indonesia may learn the advantages and disadvantages of implementing WPA in different countries. For example, WPA carried out through Marshall Plan has contributed positively to the reconstruction process of economic recovery in West Germany (Knapp et al., 1981:421-425). Generally, Marshall Plan played a significant role and intended to aid Western Europe regional growth after World War II (Long \& Eichengreen, 1991:1). Interestingly, this positive result did not happen in Turkey. In this country, Marshall Plan did not made much of a significant contribution. At first, this program added value to the economy, but unfortunately, it failed to establish sustainable welfare development in Turkey (Nurgün Koç \& Bedriye Koç, 2017:102-104). With its relatively homogeneous theory and practice and referring to WPA, Marshall Plan shows various results when implemented by countries in different regions.

The background mentioned above underlies the importance of conducting the study on IPA in Indonesia. Why is the study on IPA critical in Indonesia? Interestingly, many countries are difficult to catch up with advanced countries despite imitating the theory and practice of WPA, which is claimed to be a successful secret of western country advancement. This raises the question of the WPA compatibility level that is claimed to be universal when implemented in countries different from western countries (Cheung, 2013:257; Dwivedi, 2002:49). In addition, Indonesia, with its high pluralism, has shown the heterogeneity of social, economic, and political situations that are different from Western countries' contexts.

Pluralism has led the questions to emerge: 1) How does public administration represent and fulfil the society and government's interests in Indonesia? And 2) is the concept of indigenous public administration appropriate for being implemented by the Indonesian government and society?

\section{B. LITERATURE REVIEW}

\section{IPA: The Construction of Concept and the Basis of Rationality}

IPA as a discourse has not yet achieved what so-called establishment since it is different from WPA. IPA itself has no concept, theory or mainstream practice. WPA has the mainstream concept, theory, and practice based on rationality, formality, and meritocracy, meanwhile, IPA does not own the mainstream concept. There are various definitions of IPA. In this literature review, the following paragraphs will discuss IPA. The general definitions of IPA are firstly discussed. In this study, IPA is commonly understood as a governance or self-governing system within society (showing local aspect), and it is not adapted from WPA. 
Henderson (1995:21-22) states that IPA is the indigenous approach to administration and indigenization. It is perceived as the organization of public administration based on local wisdom and the existing self-governing system owned and implemented within society. The other studies such as Hoadley (2006:1-296), Cao (1990:1-199), Kim (2012: 217-238), and Gera (2012:2-20) also brought relatively similar ideas which emphasized on indigenous approach to administration to discuss IPA.

According to the framework of practical implementation, the study carried out by Dwyer et al. (2014:1099) revealed how the Maori community in New Zealand declined "mainstreaming" to emerge in health services and demanded indigenous health care. The same aspiration was manifested in Australia's Aboriginal Community Controlled Health Services (ACCHSs). In Canada, Heritz's study (2017:289) described how self-government agreements authorized people with law-making based on indigenous public administration. This authority covers comprehensive jurisdiction over government, economic and social development, education, health, land, and so on.

In addition, Hyo Cho's study (2006:4) revealed the specific characteristic of public administration in South Korea, where politicization is way higher than bureaucracy, so that the line between a politician and bureaucrat is blurred. For example, political officials are appointed by the members of senior bureaucrats. In another study, Sup Jun (2006:6) emphasized that public administration is a multi-dimensional phenomenon including the space for interaction, dependence or interdependence, and collaboration governmental, political, economic, technological, legal, social, and social-cultural contexts. The mainstream perspective is the macro-level theory in public administration, including bureaucracy, systematic theory, and rational choice theory used to explain institutional, functional, and economic aspects (Sup Jun 2006:7). On the contrary, developing a theory-based indigenous perspective emphasizes culture, politics, and tradition.

One of the studies on IPA in Indonesia carried out by Wibawa (2001:12-17) attempted to categorize IPA into pre-colonial IPA, colonial IPA, and post-colonial IPA. This proved that IPA practice had been established in the pre-colonial, colonial, to post-colonial times. This study could learn that although the massive infiltration of WPA through colonization but IPA still existed and stayed. After Indonesian independence, WPA has still dominated the public administration mainstream in Indonesia, survived, and impacted public administration in Indonesia

IPA is categorized into decision-making, leadership, and organization process. The early kingdoms of the archipelago placed IPA as traditional organizations (Rohdewohld, 1995:1-3). There are eight common characteristics of IPA. First, IPA is not always identical to a past. It is a practice then and now. Second, IPA is applied locally. The locality of IPA is restricted to the territory (geographical or administrative areas). Third, IPA is useful for the local community. It is an alternative to the existing WPA and has been established. Fourth, IPA has particular characteristics such as authentic and unique. It does not exist, or it is not found in other places. Fifth, IPA is self-organization and self-government. Its values are not originated from western. IPA is implemented non-formally (no standard, standardized). Sixth, IPA is closely related to bottom-up linkages. Seventh, IPA does not have to be conventional, but its presence completes what exists. Eighth, IPA is not the one-best way for all approaches but offers multiple solutions for many problems.

Using their creativity, people can conduct self-governance when dealing with special or abnormal conditions such as disaster or turmoil. By implementing IPA, people can overcome problems, escape from dependence on the government, and independently manage local resources. Utilizing local resources to overcome their problems is the fundamental essence of IPA.

People view IPA based on the specific rationale. They have their ways and strategies to deal with their problems. Without WPA presented by Religious Affairs Office, people can get marry. Without WPA presented by National Land Agency and Local Government, people can divide 
inheritance property and determine land use. Without WPA presented by Forestry Department, people can manage the forest. Without WPA presented by the Police Department and Indonesian National Armed Forces, people can establish their security system (i.e. pam-swakarsa, pecalang in Bali).

IPA is defined as indigenization which is not always identical to simple things. Otherwise, it associates with complex and challenging issues. For example, IPA deals with ethnicity, religion, race, and inter-group issues. Besides, it also manages irrigation. There is an excellent opportunity to deal with corruption in Indonesia through the implementation of IPA. This mindset is based on the reality that the governance concept is weak and powerless to become the rationale for eradicating corruption. The governance concept requires re-definition and deconstruction by giving opportunity for people to deal with their problems rationally and independently: indigenous solutions for indigenous issues.

\section{METHOD}

This research is a descriptive qualitative study since the issues require deep exploration. It is essential to explore the issues to establish complex and detailed comprehension deeply. The data sources covered books, journals, institution reports, regulations and other relevant writings of organizations, professionals, and academicians. This study applied the desk study method and data analysis spiral as analysis method (Creswell \& Poth, 2018:255). There were six stages of the data analysis spiral. The first stage was management and data codification. In this stage, all data were organized through data codification. Data codification was based on relevant keywords. For example, the critical findings were codified as indigenous, public administration, governance, bureaucracy and so forth. The second stage was reading and listing new ideas. This stage was necessary for exploring (searching) new data which had not been codified. For example, the data exploration attempted to find information regarding a state of turmoil in Aceh and Papua due to incompatible WPA with local-social context.

The next stages concerned the process of data interpretation. The codified data were described and classified under the specific theme in the third stage. The interconnected patterns were established among codified data to form a theme. For example, indigenous and public administration were interconnected to create an indigenous public administration theme. The fourth stage was data verification. This was performed by observing similar findings to determine whether or not the specific data were acceptable. For example, to argue that WPA was incompatible with the local context in Indonesia, the dynamics in Aceh and Papua were discussed to verify the data was carried out. The fifth stage was interpretation. Based on the codification, the themes were described and interpreted. For example, the incompatibility of WPA was analyzed from the IPA themes contradicted with WPA. The last stage was the presentation. The presentation was shown in the form of writing.

\section{RESULT AND DISCUSSION WPA: Mindset and Rationale}

As the theory and practice, WPA has been developed (established). The way of thinking and rationale were identified and analyzed since its emergence as conventional public administration (PA), modern PA (New Public Management), and postmodern PA. As one of the experts of traditional PA, Woodrow Wilson considered public administration as the executive and operational institution. Therefore, public administration is always interrelated with the implementation, organization, and management matter (Shafritz \& Hyde, 2017:8).

In his work entitled Politics and Administration, Goodnow defines WPA by distinguishing it from politics (Goodnow, 2017:11-13). He emphasizes further that politics is a manifestation of the purpose of the state. It means that politics is contestation over power to determine values and 
specific goals in a country from the perspectives of political parties. Meanwhile, the administration is the practical-technocratic product created and operated to achieve political values and goals by the authority. This perspective emphasizes on politics and administration dichotomy. The administration should be value-free due to its restricted function in policy implementation. Goodnow's view is opposite to the principles of IPA, which does not place public administration be value-free. The idea of IPA points out that public administration is always connected with a social, economic, and political background covering a country or community.

During the Alexander Hamilton era, Hamilton's general ideas showed the importance of strong and coordinated public administration. They emphasized that centralization in public administration was necessary. Centralization was considered essential to maintaining the main concept and the soul of the birth of the United States' human liberty.

Besides Wilson, Goodnow dan Hamilton, the other theorist of WPA is Frederick W. Taylor. In his book entitled Scientific Management, WPA is defined as management (Taylor, 2003:1). Next, it is also associated with "the best working method". Taylor's idea is supported by Henry Fayol's thought which summarizes the principles known as management principles. These principles are illustrated as follows:
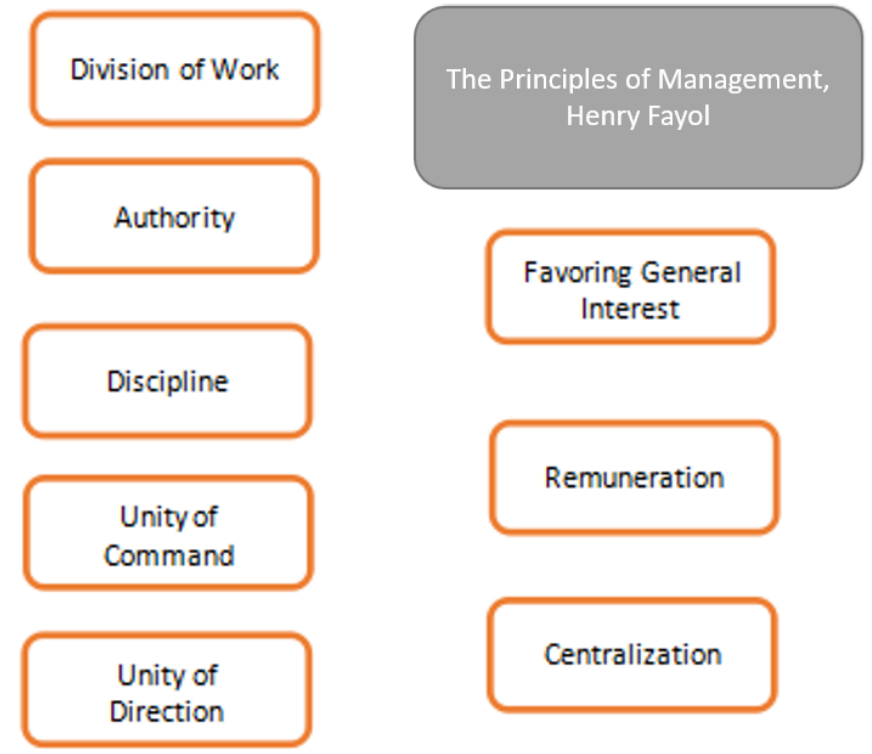

Remuneration

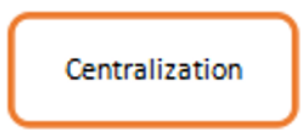

Esprit de Corps

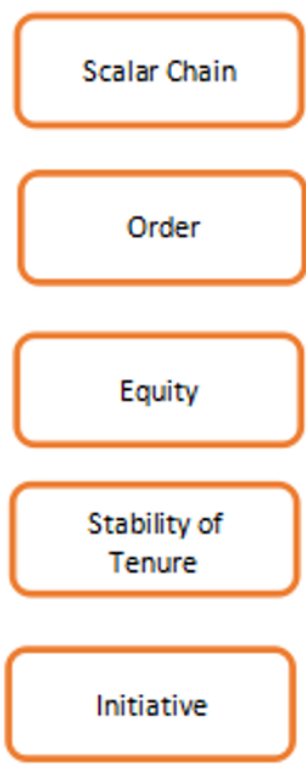

Source: Organization Theory and Public Management (Tompkins, 2005:100)

Figure 1. Management Principles by Henry Fayol

In the subsequent development, Leonard D. White (1931) is one of the influential figures in the development of WPA. In his work entitled Introduction to the Study of Public Administration, White tries to build a framework involving two primary elements of public administration. The first element is human resource management and other resources. The second element is efforts to achieve specific state goals. Furthermore, White defines public administration as efforts to achieve state goals through human resource management and other resources (Shafritz \& Hyde, 2017:1415). He further explains that management is a single process that is uniformly applied in different levels of government.

A new perspective is introduced by Luther Gulick and Max Weber. They argue that the idea of WPA is considered as an organization instead of management. In his book entitled Bureaucracy, 
Weber introduces bureaucracy as the "ideal type" of the modern organization. This ideal type of contemporary bureaucracy has the same characteristics as WPA. Weber's idea can be identified as the characteristics of bureaucracy such as clear job division, competence basis, and functional specialization. Weber conveys that bureaucracy should uphold formal supremacy in regulation, procedure and rule. Bureaucracy should own professionalism characteristics to separate between personal (privacy) and bureaucratic aspects as a civil servant who works under value-free principle.

The influence of Luther Gulick (1984) underlines that organization requires what so-called "division of work" for each working unit (Shafritz \& Hyde, 2017:85). Furthermore, it is necessary to coordinate working units based on the top-down/bottom-up pattern. In general, Gulick views the importance of coordination in public administration. Coordination becomes a vital keyword to establish efficient and productive public administration. Two things are considered as primary elements of WPA theory.

Although the term "Western" in WPA is identical to the United States of America (USA), some other countries such as France, Germany, Netherland, England, Portugal, and Spain also contribute to the development of WPA. Moreover, the ancient Greek and Roman philosophy have also a significant influence on WPA. The principles of individualism, top-down administrative culture, marketing mechanism, and democracy influence the development of WPA in the USA. In addition, WPA is also influenced by the concept of power separation and short-term solid orientation in this country.

Based on the various perspectives on WPA, it can be inferred that WPA is the concept, theory and practice of public administration which focus on different aspects. The first aspect is rationality. It points out that public administrators are the ones who should carry out public administration and should behave rationally. The idea of rationality means efficiency and value-free. In other words, public administration is based on efficiency. Meanwhile, public administrators should maintain the value-free principle. The second aspect is a formality in every aspect. The third aspect is a meritocracy which concentrates on the idea to separate between politics and administration, public and private interests, and working/performance orientation.

Public administration in Indonesia adopted and adapted from WPA has a long history. When it was first established, public administration in Indonesia (Netherlands-Indies) was highly influenced by Anglo-American thoughts and ancient Greek-Roman philosophy to fulfil greater interests of the Dutch colonial government than those of citizens (Robison, 2009:6; Wilson, 2018: 22-23). Public administration in Indonesia is pro the colonial interest dominated by a militaristic approach. The manifestation of this militaristic approach is observed from the unity of command principle.

\section{The Critiques of WPA}

Numerous experts have criticized Leonard D White's (1931) perspective towards management as a single process that can be uniformly applied. One of them is Robert Dahl. According to Dahl, the principles of public administration are not a valid concept that is universally and freely determined as moral and political goals.

WPA practice in Germany, England, the USA, and Japan has their own characteristics (Chang, 2007:77-85). In this case, to claim the universal WPA as the truth requires further discussion. Jun's study (2006:7) revealed that the WPA model could not be practically implemented towards indigenous conditions due to different politics, administration, culture and history. In some cases, implementing the western administration model causes poor impacts (dismal results) and negative consequences (Sup Jun 2006:7). According to Midgley (2006:18), the efforts to formulate a single perspective, or in other words, the worldwide WPA, through the implementation of WPA among diverse societies are likely unsuccessful because of disregarding pluralism. 
Meanwhile, the study carried out by Dwyer et al. (2014:1094) found that health service governance initiated indigenous health movements in Australia, which disregarded the existing identity and indigenous culture. Similarly, in their study, Dwyer et al. (2014:1099) also revealed that the Maori community in New Zealand declined the mainstreaming concept of health service governance and demanded to manage health services themselves. These two cases represented the situation where the implementation of WPA was counter-productive due to the complete disregard for indigenous contexts. Heritz (2017:291) states increasing capacity to form intergovernmental cooperation between Canada's indigenous and non-indigenous government. It proves that affirmation towards IPA gives positive influence compared to the whole implementation of WPA that disregarding local contexts in society.

\section{IPA: It begins with 'What', 'Where' or 'What form'?}

Scientific writings always contain certain research questions. As scientific writing, this study was initially originated from research questions that focused on the existing IPA in Indonesia appropriately used for overcoming problems in state and society. IPA is the core of the emergence of social, economic, and political institutions. It is later developed into the structural order of society, economy, and politics. Finally, this structural order achieves establishment. IPA becomes the operational and contextual public administration practice and has various labels. For example, two terms represents IPA are indigenous approaches to administration and indigenization (Henderson, 1995:17).

IPA is established, grown, and developed to fulfil the needs of Indonesian citizens. For example, the coast of Gunung Kidul has potential tourism sites. The potential tourism sites have not been developed for years because of without any budget allocation from the central or regional government. The lack of infrastructure, especially the main road access, has made the private sector reluctant to invest. Practically, WPA is not always able to deal with local-contextual problems. To cope with this problem, people from various regions initiated the creation of a tourism awareness community (Pokdarwis). This community has been involved in contributory interactions with governmental agents. Several studies supported this argument such as Irawan et al. (2018:1-9), Hidayatullah et al. (2017:467-476), and Putra (2013:225-235). IPA is also presented in local wisdom-based regulation of forest clearing by Dayak people.

There is a gap in WPA implementation among the various contextual situations that enable WPA to be discussed further. IPA is the spontaneous practice fulfilling the vacant space, for example, Pranoto Mongso of the agricultural system in Central Java and East Java. Pranoto Mongso is the reflexive IPA practice established among farmers who interacted with one another and it is influenced by natural phenomena such as weather patterns and seasonal changes (Retnowati et al., 2014:786). IPA is presented as the concept formulated carefully and established with a clear purpose. For example, the education system is based on Islamic schools (Madrasah Diniyah). This Islamic school was purposefully built and maintained to provide religious education more deeply in response to the Netherland-Indie education system (Nizah, 2016:183). Either Islamic school or mosque can exists under the national education system. After the Law of National Education System was issued in 2003, Islamic schools are recognized as part of the national education system. The uniqueness of local issues claimed that WPA's universality is still questionable.

IPA tends to be contemporary or to face urgent matters. For example, when the administration system of national marriage cannot accommodate the whole society, the unregistered marriage (nikah siri) is held. According to half of the community, the unregistered marriage institution appears since the administration system of national marriage is not inclusive, especially in financial matter. Another aspect is the national security system. The state police have no capability of comprehensively maintaining security. To this, IPA initiated the formation of smaller security 
units, namely Pam Swakarsa and Siskamling. The local administration has both thinking and working patterns. IPA is established for accommodating the needs responsively, simply, and fast. Often, IPA is contributorily intertwined with WPA.

Using the periodization concept, the division of IPA periods falls into three categories: precolonial IPA, colonial IPA, and post-colonial IPA. In his book entitled "Negara-Negara di Nusantara: Dari Negara Kota hingga Negara Bangsa", Wibawa (2001:12-17) mentioned the practice of indigenous administration when kings and nobles ruled this country in the past time. According to Wibawa, indigenous administration practice included the military, taxation and tribute, decision-making, and leadership succession. Many works that discus the existence of IPA in several countries are also written by some scholars, such as Hoadley (2006:1-296), Cao (1990:1-199), Kim (2012:217-238), and Gera (2012:2-20). They prove the existence of IPA in Indonesia, China, South Korea, and the Philippines.

\section{The Practice of IPA and WPA in China}

China is a fascinating country and has the oldest IPA history. IPA was established, had space to develop, and metamorphosed. It was less appropriate not to include the discussion of IPA in China. The model of IPA and its implementation in thiscountry will become the main focus in this part.

\section{Centralization}

Based on Confucianism, centralization is the main pillar of Chinese administrative building (Cao, 1990:53). In China, centralization is widely applied in administration, politics, military, and law (Cao, 1990:91-92). Centralization supports the assumption that power-sharing is much more effective than power separation (Cao, 1990:190). In China, centralization is seen from a singleparty system, top-down policy cycle, and centralized government system, prioritizing the executives at the pinnacle of power (yiyuanhua leadership). It effectively affects the policy formulation process by eliminating repetitive discussion and consultation. Besides, centralization also promotes a solid bureaucratic structure and implements a relatively effective policy to deal with intervention by the outside parties.

However, the solid centralization in China often causes several problems. First, it is marked by the potential emergence of authoritarianism. The most recent amendment to the Constitution in China likely brings the opportunity for Xi Jin Ping to serve more than two terms as president, making Xi becomes the strongest figure in China (Shirk, 2018:23). Second, it causes a worry about the potential emergence of the surveillance state. When reaching the uncontrolled stage, executive positions with strong administrative authority and policy-making may threaten citizens' civil rights. The government of China widely carries out monitoring and censor towards the citizens, consequently it violates the civil rights of people to keep their privacy (Bartow, 2013:856).

\section{Merit System}

The second principle of administration in China is meritocracy. Meritocracy and centralization are used to eliminate the abuse of power potential. It had been existed before modern China was established. It even existed in the era of ancient China, the period when the emperors ruled this country. Both technical and political skills were essential for the bureaucrats. The competent bureaucrats were appreciated by assigning higher social status among the Chinese community (Cao, 1990:56). In addition, their job career was also guaranteed.

Meritocracy is believed to establish professional, competent, and good administration. The government of China places human resource organization as a vital asset (Cao, 1990:56). Due to its importance, the merit system is applied for the basic principle of selection of government's human resources (Kim, 2012:219). In addition, their job career is also guaranteed. To appoint 
competent officials, the government of China vigorously and intensively prepares the training for public officials. The best human resources will be selected based on a merit system through extremely competitive selection. They will support the principle of rule by man, contradicting the rule of law principle. This principle supports the man supremacy over the legal rules (Cao, 1990:133-134).

\section{Independence (Self-governing, Self-reliance, Autonomy)}

The final principle of public administration in China is independence, rooted in the political isolation policy era. China's isolation policy leads to the reinforcement of independence values. Clan system and culture are the important elements establishing the foundation of independence in China (Cao, 1990:74). Freedom is manifested through the production of goods and services. It is all started from the orientation of independence in food policy. Three kinds of supporting programs developed by the government of China are the industrial independence program, military independence program, and science and technology independence program. The principle of independence shapes the pattern of political-economic policy in China, characterized by protectionism and import substitution (Kroeber, 2016:66).

The administration model in China unites between a cultural-autonomous mindset and a cultural-efficient mindset. This statement indicates that independence can be achieved without sacrificing efficiency. Independence must refer to the efficiency aspect that promotes international competitiveness. Independence as protectionism and import substitution can lead China to achieve efficiency and effectiveness. It shows a connection with China's comparative supremacy of labour and natural resources. Besides independence, public administration in China orientates towards productivity. Being productive means that public administration creates more outcomes and profits rather than spending money. The system which appreciates those who have contributed positively to productivity is called the "contract responsibility system" (Zerenzhi) (Cao, 1990:46-48).

\section{E. CONCLUSION \\ Critical Reflection towards WPA and IPA}

Based on the analysis, it can be concluded that WPA as the concept, theory, and practice is a mainstream in public administration. However, the implementation of WPA in the heterogeneous community in the world has weaknesses and incompatibilities. The heterogeneity must be recognized and implemented to view potential self-governing systems in society. On the other hand, IPA, as an alternative discourse, can provide a proper and appropriate solution to deal with any weakness and incompatibility of the WPA implementation. It is proven by two primary cases, China and Indonesia, and the other cases in different countries such as Australia, New Zealand, Canada, and South Korea. Both Indonesia and China have the potential to apply IPA. The distinct differences between the two countries are: China implements IPA formally, more structurally, systematically, and massively. Meanwhile, Indonesia implements IPA informally and incrementally instead of sporadically.

There are increasing demands for reconstructing and reviewing WPA (government and governance) applied in Indonesia. The main reason is related to the insignificant contribution of WPA to deal with problems in Indonesia. WPA often disregards local and socio-cultural conditions with its one-size-fits-all prescription approach and strategy. As a result, many people shift from WPA to IPA and finally choose IPA instead of WPA. Some activities that represented the implementation of IPA are non-governmental security agency (Hansip), agricultural institution (pranoto mongso), and tourism institution (Pokdarwis).

The findings of this study are expected to pave the way for establishing and developing the concept and theory of IPA through further researches and discussions. The scope of the future 
studies can be directed at the establishment, development, interaction of IPA-WPA and the impacts might be created by their interaction.

\section{Acknowledgements}

The researchers would like to express a deepest gratitude to the Faculty of Social and Political Sciences, Universitas Gadjah Mada, which has supported this research team through the Faculty Research Grant Program. Thanks also go to lectures at Department of Management and Public Policy who have contributed to developing the idea for this research.

\section{Contributorship}

The corresponding author is the main author, idea developer, and correspondence. The second co-author contributes to the idea development and technical writing on Western Public Administration (WPA). The third co-author contributes to the idea development and technical writing on the exploration towards Indigenous Public Administration (IPA) cases in Indonesia and other countries.

\section{REFERENCES}

Acemoglu, D., \& Robinson, J. A. (2012). Why Nations Fail: The Origins of Power, Prosperity and Poverty. Crown Publishers.

Bartow, A. (2013). Privacy Laws and Privacy Levers: Online Surveillance Versus Economic Development in the People's Republic of China. 74 Ohio St. L.J, 74(6), 853-893. http://digitalcommons.pace.edu/lawfaculty/922.

Bourgon, J. (2007). Responsive, Responsible and Respected Government: Towards a New Public Administration Theory. International Review of Administrative Sciences, 73(1), 8-24. https://doi.org/10.1177/0020852307075686

Bozeman, B. (2007). Public Values and Public Interest: Counterbalancing Economic Individualism (B. A. Radin, Ed.). Georgetown University Press.

Bryson, J. M., Crosby, B. C., \& Bloomberg, L. (2014). Public Value Governance: Moving beyond Traditional Public Administration and the New Public Management. Public Administration Review, 74(4), 445-454. https://doi.org/10.1111/puar.12238

Cao, D. (1990). Public Administration in Post-Mao China (1978-1988): A Theoretical Analysis through Rosenbloom's Model.

Chang, H. J. (2007). Institutional Change and Economic Development (H. J. Chang, Ed.). United Nations University Press.

Cheung, A. B. L. (2013). Can There be an Asian Model of Public Administration? Public Administration and Development, 33(4), 249-261. https://doi.org/10.1002/pad.1660

Creswell, J. W., \& Poth, C. N. (2018). Qualitative Inquiry and Research Design: Choosing among Five Approaches (4th ed.). SAGE Publications.

Deda, A. J., Suriel, D., \& Mofu, S. (2014). Masyarakat Hukum Adat dan Hak Ulayat di Provinsi Papua Barat sebagai Orang Asli Papua Ditinjau dari Sisi Adat dan Budaya: Sebuah Kajian Ethnografi Kekinian. Jurnal Administrasi Publik, 11(2), 11-19. www.unipa.ac.id

Drechsler, W. (2013). Three Paradigms of Governance and Administration: Chinese, Western and Islamic. Society and Economy, 35(3), 319-342. https://doi.org/10.1556/SocEc.35.2013.3.3

Dwivedi, O. P. (2002). Challenges in Public Administration around the World. In G. Bertucci \& M. Duggett (Eds.), The Turning World: Globalization and Governance at the Start of thee 21 st Century (pp. 47-54). UNDESA-IIAS Joint Publication.

Dwyer, J., Boulton, A., Lavoie, J. G., Tenbensel, T., \& Cumming, J. (2014). Indigenous Peoples' Health Care: New Approaches to Contracting and Accountability at the Public Administration 
Frontier. Public Management Review, 16(8), 1091-1112. https://doi.org/10.1080/14719037.2013.868507

Gera, W. (2012). Compromises of Representation: The Politics of Diversity in Philippine Bureaucracy.

Goodnow, F. J. (2017). Politics and Administration: A Study in Government. Routledge.

Gulick, L. (1984). The Metaphors of Public Administration. Public Administration Quarterly, 8(3), 369-381. http://www.jstor.org/stable/41575698

Henderson, K. M. (1995). Reinventing Comparative Public Administration Indigenous Models of Study and Application. International Journal of Public Sector Management, 8(4), 17-25. https://doi.org/10.1108/09513559510096246

Heritz, J. (2017). The Multiplying Nodes of Indigenous Self-Government and Public Administration. Canadian Public Administration, 60(2), 289-292. https://doi.org/10.1111/capa.12214

Hidayatullah, S., Rachmawati, I. K., Khouroh, U., \& Windhyastiti, I. (2017). The Effectivity of "Pokdarwis" Role on Successfully Marketing of Tourism Village Towards "Mega Tourism: Batu City For The World." Sustainable Development Goals 2030 Challenges and Its Solutions, 467-476.

Hillman, B. (2013). Public Administration Reform in Post-Conflict Societies: Lessons from Aceh, Indonesia. Public Administration and Development, 33(1), 1-14. https://doi.org/10.1002/pad.1643

Hoadley, M. C. (2006). Quo Vadis Administrasi Negara Indonesia: Antara Kultur Lokal dan Struktur Barat (1st ed.). Graha Ilmu.

Hyo Cho, Y. (2006). IRPA Forum: Seeking Indigenous Theories of Korean Public Administration. International Review of Public Administration, 10(2), 1-19. https://doi.org/10.1080/12294659.2006.10805065

Irawan, H., \& Raza'i, T. S. (2018). Pengembangan Ekowisata Bahari Berbasis Keanekaragaman Hayati pada Pokdarwis Pengundan Bintan Mangrove di Desa Pengundan Kabupaten Bintan. Jurnal Pengabdian Kepada Masyarakat Maritim, 1(1), 1-9.

Kim, P. S. (2012). A Historical Overview of Korean Public Administration: Discipline, Education, Association, International Cooperation and beyond Indigenization. International Review of Administrative Sciences, 78(2), 217-238. https://doi.org/10.1177/0020852312438043

Knapp, M., Stolper, W. F., \& Hudson, M. (1981). Reconstruction and West-Integration: The Impact of the Marshall Plan on Germany. Journal of Institutional and Theoretical Economics, $137,415-433$.

Kroeber, A. R. (2016). China's Economy: What Everyone Needs to Know. Oxford University Press. Long, J. B., \& Eichengreen, B. (1991). The Marshall Plan as a Structural Adjustment Program.

Midgley, J. (2006). IRPA Forum: Seeking Indigenous Theories of Korean Public Administration. International Review of Public Administration, 10(2), 1-19. https://doi.org/10.1080/12294659.2006.10805065

Nizah, N. (2016). Dinamika Madrasah Diniyah: Suatu Tinjauan Historis. Jurnal Penelitian Pendidikan Islam, 11(1), 181-202.

Nurgün Koç, \& Bedriye Koç. (2017). Affects of Marshall Plan on Turkish Economy. Sociology Study, 7(2), 83-121. https://doi.org/10.17265/2159-5526/2017.02.003

Putra, T. R. (2013). Peran Pokdarwis dalam Pengembangan Atraksi Wisata di Desa Wisata Tembi, Kecamatan Sewon, Kabupaten Bantul. Jurnal Pembangunan Wilayah Dan Kota, 9(3), 225235.

Retnowati, A., Anantasari, E., Marfai, M. A., \& Dittmann, A. (2014). Environmental Ethics in Local Knowledge Responding to Climate Change: An Understanding of Seasonal Traditional Calendar Pranoto Mongso and its Phenology in Karst Area of GunungKidul, Yogyakarta, 
Indonesia. Procedia Environmental Sciences, 20, 785-794. https://doi.org/10.1016/j.proenv.2014.03.095

Robison, R. (2009). Indonesia: The Rise of Capital (1st ed., Vol. 1). Equinox Publishing.

Rohdewohld, R. (1995). Public Administration in Indonesia. Montech.

Shafritz, J. M., \& Hyde, A. C. (2017). Classics of Public Administration (8th ed.). Cengage Learning.

Shirk, S. L. (2018). China in Xi's "New Era." Journal of Democracy, 29(2), 1-1.

Sup Jun, J. (2006). IRPA Forum: Seeking Indigenous Theories of Korean Public Administration. International Review of Public Administration, 10(2), 1-19. https://doi.org/10.1080/12294659.2006.10805065

Taylor, F. W. (2003). Scientific Management (K. Thompson, Ed.; 4th ed., Vol. 1). Routledge.

The College of Public Administration University of the Philippines. (1981). The Methodological Aspects of Adaptation of Public Administration for Endegenous Development in the SocioCultural Contexts of the Southeast Asian Region.

Tompkins, Jonathan. (2005). Organization Theory and Public Management. Wadsworth, Cengage Learning.

Wang, T. Y., \& Liu, H. (2018). An Emerging Asian Model of Governance and Transnational Knowledge Transfer: An Introduction. Journal of Asian Public Policy, 11(2), 121-135. https://doi.org/10.1080/17516234.2018.1477030

White, L. D. (1931). The Civil Service in the Modern State. The American Political Science Review, 25(2), 452-454. https://www.jstor.org/stable/1947679

Wibawa, S. (2001). Negara-Negara di Nusantara: Dari Negara Kota hingga Negara Bangsa dan dari Modernisasi hingga Reformasi Administrasi. Gadjah Mada University Press.

Wilson, I. D. (2018). Politik Jatah Preman: Ormas dan Kuasa Jalanan di Indonesia Pasca Orde Baru. Marjin Kiri. 
This page is left blank. 